\title{
Does the Presence of Detached Root Border Cells of Zea mays Alter the Activity of the Pathogenic Nematode Meloidogyne incognita?
}

\author{
S. Rodger, A. G. Bengough, B. S. Griffiths, V. Stubbs, and I. M. Young
}

First and fifth authors: Scottish Informatics Mathematics Biology and Statistics (SIMBIOS) Centre, School of Science and Engineering, University of Abertay Dundee, Bell Street, Dundee, DD1 1HG, Scotland, U.K.; and second, third, and fourth authors: Scottish Crop Research Institute, Dundee, DD2 5DA, Scotland, U.K. Accepted for publication 25 March 2003.

\begin{abstract}
Rodger, S., Bengough, A. G., Griffiths, B. S., Stubbs, V., and Young, I. M. 2003. Does the presence of detached root border cells of Zea mays alter the activity of the pathogenic nematode Meloidogyne incognita? Phytopathology 93:1111-1114.

The root-knot nematode Meloidogyne incognita is a major pathogen of a range of important crops. Currently, control is typically achieved by the use of nematicides. However, recent work suggests that manipulating the

gated the attractiveness of border cells to $M$. incognita and the response of the nematode to border cells in close proximity. We found very limited attraction, in that nematodes did not preferentially alter direction to move toward the border cells, but a large and significant increase in nematode speed was observed once they were in the immediate vicinity of border cells. We discuss the results in the context of physical and biological mechanisms in relation to the control of pathogenic nematodes.
\end{abstract} ability of roots to slough off border cells, which then act as a decoy to the nematode, can significantly decrease damage to the roots. We investi-
Additional keywords: habitat, kinesis, maize, taxis.
In any environment, the manner in which and the rate at which organisms acquire and respond to information is of crucial importance to their survival and dispersal (7). For plant-pathogenic nematodes, the speed at which they can seek, identify, and find plant hosts determines their survival and the resultant damage to plants. The projected decrease in the degree of pesticide usage has led researchers to seek alternative, more environmentally benign strategies. Recently, Hawes and Pueppke (11) postulated that root border cells, which are detached or sloughed from the root cap, may offer roots protection from pathogenic nematodes by acting as decoys dispersed in the soil around the elongating root tip. This is an attractive hypothesis, as very large numbers of cells may be detached during the life of a root tip (10), and the cells remain functioning in the soil for up to 7 days after detachment (17).

For border cells to act as effective deterrents to nematodes, they must attract nematodes away from the root and keep them in the vicinity of the cells for some finite time. Thus the border cells, or attendant mucilage or bacteria, must act as an attractant by emitting infochemicals into the soil system, setting up a chemoattractant gradient that guides nematodes to them (21). Once nematodes are in contact with border cells, nematode activity must be altered to deter further migration toward vulnerable root tissues.

Root border cells have been observed acting as both an attractant and a deterrent to the root-knot nematode Meloidogyne incognita (Chitwood, 1949) (22). Remarkably, for the first time, localized chemotactic attraction of nematodes by border cells from pea roots has been observed (22). However, the degree and rate of attraction of nematodes to detached cells has not been investigated, and this is important in determining the potential effect of such a phenomenon in field situations where nematodes would have to be decoyed away from elongating roots.

Corresponding author: I. M. Young; E-mail address: imy@tay.ac.uk

Publication no. P-2003-0710-01R

(c) 2003 The American Phytopathological Society
In this study we seek to quantify the degree of chemotaxis when $M$. incognita is in the vicinity of maize border cells. Further we develop this theme and investigate the activity of nematodes when directly challenged by border cells. This work developed from our previous work on chemotaxis of Caenorhabditis elegans (Maupas, 1900) $(1,2,21)$ and aims to quantify nematode-border cell interactions over time.

\section{MATERIALS AND METHODS}

Zea mays is a suitable host of $M$. incognita (21). Seeds of the maize cultivars Renard and Mephisto were surface-sterilized in $2 \%$ calcium hypochlorite for $10 \mathrm{~min}$ and then rinsed six times with sterile distilled water. The seeds were then germinated at $25^{\circ} \mathrm{C}$, between layers of moistened sterile filter paper at an angle of $30^{\circ}$ to the vertical.

Eggs of M. incognita line 19 (isolate collection of the Scottish Crop Research Institute, Dundee, U.K.) were extracted from chopped roots of infected glasshouse-grown tomato (Lycopersicon esculentum), 8 weeks after inoculation, by immersion in $50 \mathrm{ml}$ of $1 \%$ sodium hypochlorite for $4 \mathrm{~min}$. The eggs were collected on a 38 - $\mu \mathrm{m}$-pore-size metallic sieve and washed gently several times to remove all sodium hypochlorite. To obtain second-stage juveniles (J2), eggs were hatched in tap water above a 20 - $\mu$ m-pore-size nylon fiber screen for 2 days at $25^{\circ} \mathrm{C}$, and $\mathrm{J} 2$ were then collected below the screen.

Effect of border cells on the chemotactic response of $M$. incognita. A $4.5-\mathrm{cm}$-diameter petri dish containing $1.2 \%$ technical agar (Oxoid Ltd., Hampshire, U.K.) was placed on a template of concentric circles divided into quadrants drawn on an acetate sheet (Fig. 1). A maize seedling was selected, with a root approximately $30 \mathrm{~mm}$ long, and the bead of border cells and associated mucilage on the tip was carefully wiped over the surface of the outer test quadrant (Fig. 1). Control plates received no treatment. Three replicates were prepared for each treatment. All plates were sealed with self-sealing film and incubated at $25^{\circ} \mathrm{C}$ overnight (approximately $18 \mathrm{~h}$ ). A $2-\mu \mathrm{l}$ drop of sterile distilled water was 
pipetted into the central ring of each replicate plate. Ten actively motile $\mathrm{J} 2$ were selected microscopically and transferred, by means of an eyelash mounted on a wooden pick, to each water drop. The surface tension of the drop initially contained the nematodes. The drops were dried simultaneously in laminar airflow until no free water was observed. The number of nematodes that moved out of the central ring into each annulus of the test and control quadrants (Fig. 1) were counted directly by microscopic observations at 20 -min intervals over a period of $160 \mathrm{~min}$. The assay was conducted at room temperature $\left(20^{\circ} \mathrm{C}\right)$. The sampling periods and test assays were based on many preliminary studies of border cellnematode interaction.

An attraction index was calculated as

$$
\frac{A t}{L t * N t} \sum \frac{L n(T n-C n)}{A n}
$$

where $A n$ represents the area of a quadrant section $(1,2$, or 3); $L n$, the diameter of the annulus in that section; $T n$ and $C n$, the number of nematodes in sections successively closer to the bacterial streak ( $T 1$ to $T 3$ ) and the number in sections successively farther away from it ( $C 1$ to $C 3$ ) (Fig. 1); $A t$, the total exploitable area; $N t$, the total number of nematodes; and $L t$, the total diameter of the examined area. This attraction index was developed from an index used previously $(3,9)$, but it is significantly different in being based on the available exploitable area in each section of a quadrant, and as such it represents a weighted average. The previous attempts at defining an attraction index ignored the effect of area, which is clearly crucial in any examination of patterns of foraging toward a food source. The complete experiment was repeated twice (Trial 1 and Trial 2). Similar results of comparable magnitude were obtained, and hence only the results of Trial 1 are presented.

Effect of border cells on the behavior of $M$. incognita $\mathbf{J} 2$. Test arenas were prepared by placing sterile metal washers (aperture, $8 \mathrm{~mm})$ in sterile petri plates $(4.5 \mathrm{~cm}$ in diameter) and filling the washer aperture with $1.2 \%$ technical agar. Three treatments were used: (i) washed root border cells and J2 nematodes, (ii) glass beads (ballotini) (Jencons-PLS, Leighton Buzzard, U.K.) and $\mathrm{J} 2$ nematodes, and (iii) $\mathrm{J} 2$ nematodes only, as a control treatment. The glass bead treatment acted to test the behavior of nematodes in the presence of inert physical objects similar in size to border cells.

Seven root tips of intact seedlings (approximately $30 \mathrm{~mm}$ long) were immersed in $1 \mathrm{ml}$ of sterile distilled water for $20 \mathrm{~min}$, and border cells were removed by agitating the water gently with a Pasteur pipette. Border cells were pelleted at 7,000 rpm for $4 \mathrm{~min}$ and then washed twice, with further centrifugation, in sterile distilled water to remove residual root tip exudates and associated

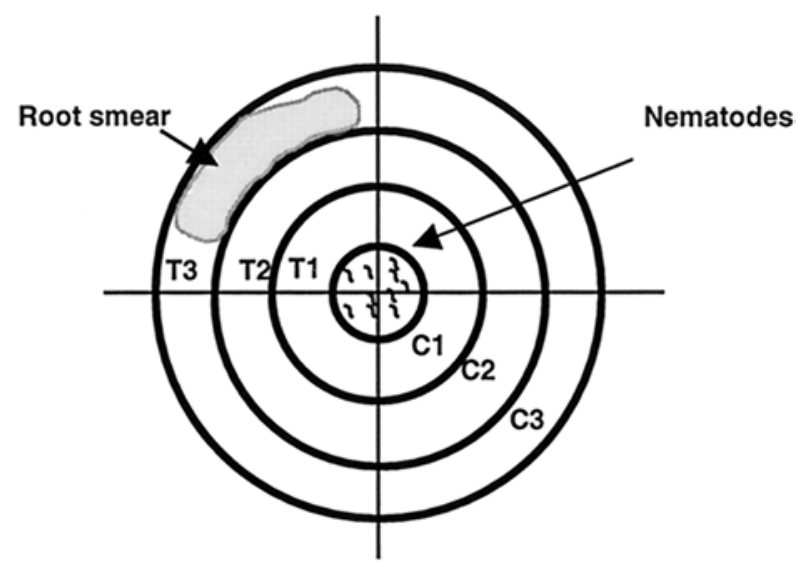

Fig. 1. Schematic diagram of the experimental design used in this assay. T1, $\mathrm{T} 2$, and $\mathrm{T} 3$ are the annuli of the test quadrant, and $\mathrm{C} 1, \mathrm{C} 2$, and $\mathrm{C} 3$ are the annuli of the control quadrant. mucilage. Glass beads, ranging from 0 to $0.05 \mathrm{~mm}$ in diameter, were washed and sieved to obtain a final size range of 0.038 to $0.05 \mathrm{~mm}$, which is comparable to the dimensions of root border cells. The glass beads were then dried and heat-sterilized prior to use. The final concentration of border cells and glass bead samples was altered, by direct counts, to between 50 and 60 per microliter. A $1-\mu l$ drop of either a suspension of border cells or a suspension of glass beads was pipetted onto the center of a test arena and allowed to dry at room temperature until no free water was observed on the surface. J2 nematodes were observed microscopically, and 10 active individuals were transferred to the center of each test arena. Three replicates of each treatment were tested.

Each test arena was viewed microscopically by a video camera with a video capture system (Visilog, Bath, U.K.). A time-lapse recording was made over $30 \mathrm{~min}$, with a frame interval of $5 \mathrm{~s}$. Each nematode was tracked manually, and positional coordinate data were recorded. Thus, for each treatment, 30 nematode trails were recorded and analyzed. Average speed, total distance moved, and curviness of the trail were recorded. The data were analyzed as a randomized block design by ANOVA in Genstat 4.2. Data were log-transformed where the transformation was required.

\section{RESULTS}

The effect of border cells and associated root tip exudates on the chemotactic response of larvae of Meloidogyne is shown in Figure 2. Over the duration of the assay, the nematodes in the control treatment generally remained in the central ring. In contrast, when border cells were present, nematode movement fluctuated from the control quadrant (maximum attraction value of -0.640) to the test quadrant (maximum attraction value of 0.294).

Additional microscopic observations suggested increased activity of Meloidogyne larvae when they were directly challenged by maize root border cells. Therefore a quantitative bioassay was developed to test for potential kinesis interaction, in the form of a significant increase in average nematode speed.

Figure 3 compares the effect of the three experimental treatments on average nematode speed. There were highly significant differences between the three treatments $(P<0.0001)$. Average speed was greatest when border cells were present and lowest in the absence of border cells and glass beads. In the presence of glass beads, nematode speed was also significantly greater than in the control treatment $(P<0.001)$.

There was no treatment effect on the curviness of trails (Fig. 4), defined as the actual distance covered by a nematode divided by the straight-line distance. This value was calculated as an interpretation of nematode foraging strategies (1).

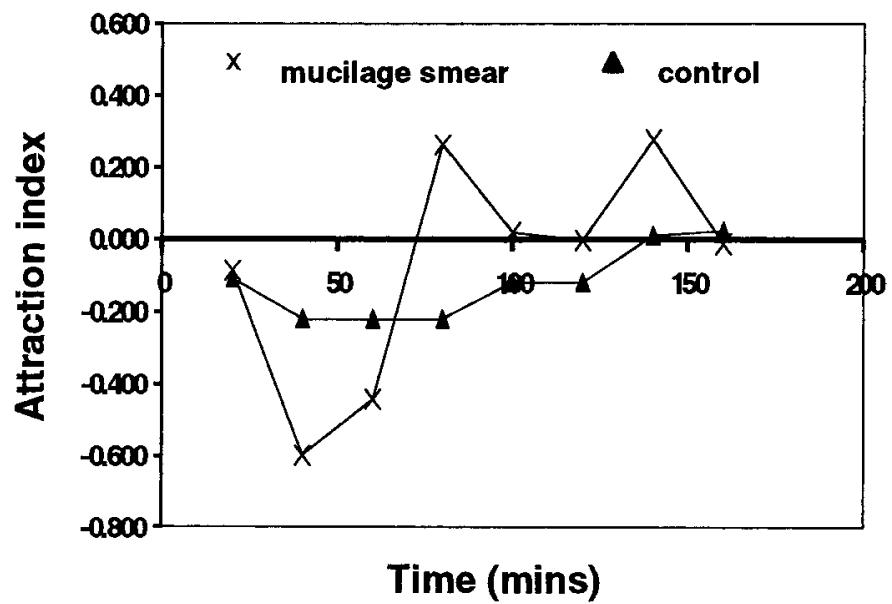

Fig. 2. Chemotactic response of Meloidogyne incognita to border cells of Zea mays and associated root tip exudates. 


\section{DISCUSSION}

Meloidogyne spp. are highly specialized, sedentary endoparasites, their most preferred feeding site being the zone of cellular elongation (6). They are unable to utilize border cells for growth. Yet it is the root apex, ensheathed in border cells, which appears to attract them in significant numbers (22). Similar observations of zoospores of soilborne fungi and host roots have been made (8).

Our results suggest that whilst there is an attraction between root-knot nematodes and border cells, it is a weak attraction. The maximum attraction index, representing $100 \%$ of the nematodes reaching the border cells, is 4.5 . The average value reached, in this experiment, was 0.240 , or about $5 \%$ of the maximum. In other unpublished work, we attained attraction indices of $4.5(100 \%$ nematode attraction) using this experimental system with C. elegans challenged by an array of bacterial species. Despite this weak attraction, it should be recognized that a wetting event of a single maize root tip could produce several thousand border cells (11), which would occupy a significant volume around the root tip. Therefore, even if nematodes were randomly foraging (or attracted by some other infochemical not represented in our experimental system), there would be a high probability that they would encounter detached border cells. The question is, What happens when this encounter takes place?

When nematodes are directly challenged by border cells, their speed doubles, compared to that of a control with no potential

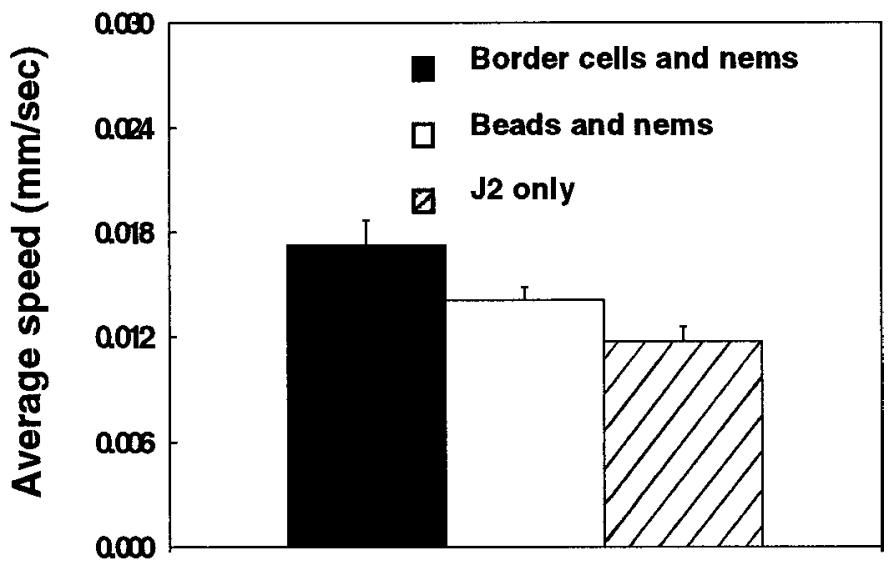

Treatment

Fig. 3. Comparison of the effect of the three experimental treatments on average nematode speed. The error bars denote the standard error of the mean.

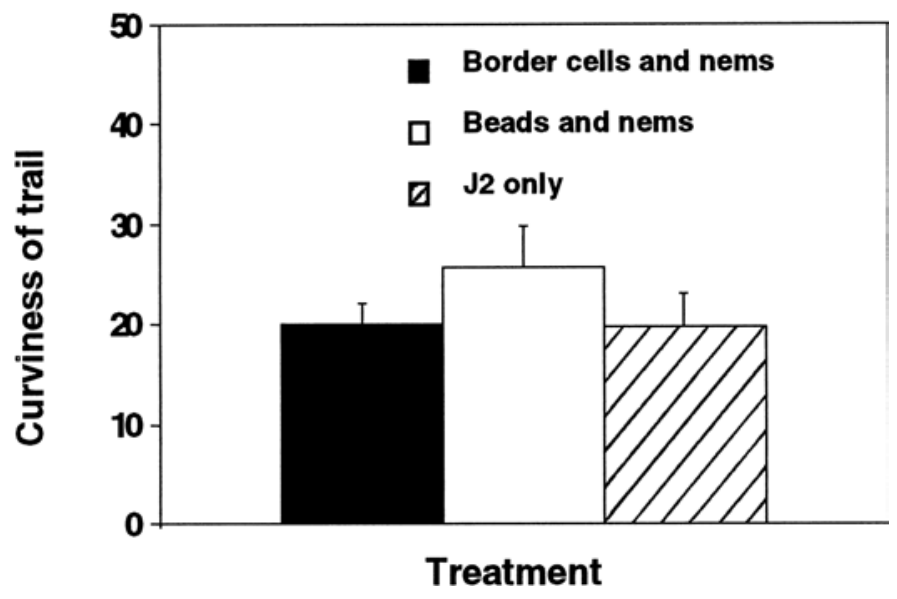

Fig. 4. Comparison of the effect of the three experimental treatments on the curviness of nematode trails. This is the value obtained when the actual distance covered by a nematode is divided by the straight-line distance. The error bars denote the standard error of the mean. attractant. The suggestion is that kinesis rather than chemotaxis is operating at this scale. Additional observations show that nematodes make rapid and frequent physical connections with single detached border cells. Interestingly, not all of this increase in speed is of biological origin. Half of the increase can be attributed to the physical presence of an obstacle, as in our glass bead experiments nematode speed also significantly increased. This physical effect is most probably a combination of the presence of the glass beads and the associated water meniscus surrounding each bead. Nematode movement in soil is typically restricted to water films surrounding pore walls, and the size of the water film and the associated surface tension of the film play a significant role in determining the rate of movement of both the organisms and the attractant $(19,21)$. It is probable that similar water films surrounding border cells play a significant role in mediating the activity of nematodes and that the effect we observe when nematodes are challenged by detached border cells is a combination of biological and physical processes.

Border cells remain active for up to 7 days after detachment from the root cap and exude an array of potential infochemicals, such as proteins, carbohydrates, and other extracellular products (17). Carbon dioxide has been strongly implicated as one of the factors attracting plant-parasitic nematodes to plant roots $(13,14$, $18)$, as has redox potential or an electric field $(13,16)$. It is important to note that in the soil environment, border cells are associated with substantial populations of microorganisms that have also been shown to influence the movement of plant-parasitic nematodes $(4,5,15)$. It is highly probable therefore that nematodes use bacteria in the recognition of host roots.

Whilst significant chemoattraction has been noted between pathogenic nematodes and detached border cells (10), no rigorous analysis of the attraction has been carried out. The answer may lie in the identification and manipulation of specific chemicals involved in this biological recognition phenomenon, as evidenced by the combination of weak chemotaxis and strong kinesis found in our experiments. Under normal conditions, root border cells adhere to rhizosphere soil, never moving more than 1 or $2 \mathrm{~mm}$ from the root surface - this is roughly the maximum diameter of the adhering soil (20), usually termed rhizosheath soil. At the local scale, simple probabilities state that there will be a significant interaction between organisms and detached border cells, as they will litter or line any path toward the roots. Therefore the density of detached cells per volume of soil and the ability of the cells to retain the interest of the pathogen are key ingredients in the role of the cells in reducing pathogen attack on the plant root. It has been predicted that for maize in loose sand about $10 \%$ of the surface of the root cap is covered with border cells, and in compacted sand the coverage increases to $100 \%$ (12), with a concomitant increase in the release of border cells into the rhizosphere. The fractional area of the root elongation zone covered with border cells will be rather smaller than this (about $45 \%$ in the compact treatment), because of its greater surface area (A. G. Bengough, unpublished data). Nevertheless, it is clear that at slow rates of root elongation in compacted soil, the density of border cells will be relatively greater around the root zone. Whether this truly represents a barrier to nematode infection of the root requires further experiments to be performed in soil where border cell production is somehow manipulated.

\section{ACKNOWLEDGMENTS}

We thank A. Holt and J. Wishart for their expert help and advice with respect to the nematode cultures and $\mathrm{H}$. Staines (Scottish Informatics Mathematics Biology and Statistics Centre) for statistical advice with respect to the attraction index. This work was funded by the Biotechnology and Biological Sciences Research Council. The Scottish Crop Research Institute receives grant-in-aid from the Scottish Executive Environment and Rural Affairs Department. 


\section{LITERATURE CITED}

1. Anderson, A. R. A., Sleeman, B. A., Young, I. M., and Griffiths, B. S. 1997. Nematode movement along a chemical gradient in a structurally heterogeneous environment. 2. Theory. Fundam. Appl. Nematol. 20:165-172.

2. Anderson, A. R. A., Young, I. M., Sleeman, B. A., Griffiths, B. S., and Robertson, W. M. 1997. Nematode movement along a chemical gradient in a structurally heterogeneous environment. 2. Theory. Fundam. Appl. Nematol. 20:157-163.

3. Andrew, P. A., and Nicholas, W. L. 1976. Effect of bacteria on dispersal of Caenorhabditis elegans (Rhabditidae). Nematalogica 22:451-461.

4. Bergman, B. H. H., and Van Duuren, A. J. 1959. Het bietencystenaaltje en zijn bestrijding. VII. De werking van stof wisselings producten van sommige micro-organismen op de larven van Heterodera schachtii. Meded. Inst. Suikerbiet 29:25-53.

5. Bird, A. F. 1959. The attractiveness of roots to the plant parasitic nematodes Meloidogyne javanica and M. hapla. Nematalogica 4:322-335.

6. Cohn, E., Koltai, H., Sharon, E., and Spiegel, Y. 1996. Root-nematode interactions: Recognition and pathogenicty. Pages 783-796 in: Plant Roots: The Hidden Half. 2nd ed. Y. Waisel, A. Eshel, and U. Kafkafi, eds. Marcel Dekker, New York.

7. Dusenberry, D. B. 1992. Sensory Ecology. W. H. Freeman, New York.

8. Goldberg, N. P., Hawes, M. C., and Stanghellini, M. E. 1989. Specific attraction to and infection of Pythium dissotocum. Can. J. Bot. 67:17601767.

9. Grewal, P. S., and Wright, D. J. 1992. Migration of Caenorhabditis elegans (Nematoda: Rhabditidae) larvae towards bacteria and the nature of the bacterial stimulus. Fundam. Appl. Nematol. 15:159-166.

10. Hawes, M. C., Brigham, L. A., Wen, F., Woo, H. H., and Zhu, Y. 1998. Function of root border cells in plant health. Annu. Rev. Phytopathol. 36:311-327.
11. Hawes, M. C., and Pueppke, S. G. 1986. Isolated peripheral root cap cells: Yield from different plants, and callus formation from single cells. Am. J. Bot. 73:1466-1473.

12. Iijima, M., Griffiths, B. S., and Bengough, G. A. 2000. Sloughing of cap cells and carbon exudation from maize seedling roots in compacted sand. New Phytol. 145:477-482.

13. Jones, F. G. W. 1960. Some observations and reflections on host finding by plant nematodes. Meded. Landbouwhogesch. Gent 25:1009-1024.

14. Klinger, J. 1959. Anziehung von Collembolen und Nematoden durch Kohlendioxyd-guellen. Mitt. Schweiz. Entomol. Ges. 32:311-316.

15. Linford, M. B. 1939. Attractiveness of roots and excised shoot tissues to certain nematodes. Proc. Helminthol. Soc. Wash. 6:11-18.

16. Sukul, N. C., Das, P. K., and Ghosh, S. K. 1975. Cation-mediated orientation of nematodes under electrical fields. Nematalogica 21:145-150.

17. Vermeer, J., and McCully, M. E. 1982. The rhizosphere in Zea-New insights into its structure and development. Planta 156:45-61.

18. Viglierchio, D. R. 1961. Attraction of parasitic nematodes by plant root emanations. Phytopathology 51:136-142.

19. Wallace, H. R. 1958. Movement of eels worms. 1. The influence of pore size and moisture content of the soil on the migration of larvae of the beet eelworm, Heterodera schachtii Schmidt. Ann. Appl. Biol. 46: 74-85.

20. Young, I. M. 1998. Biophysical interactions at the root: soil interface: A review. J. Agric. Sci. 130:1-7.

21. Young, I. M., Griffiths, B. S., Robertson, W. M., and McNicol, J. W. 1998. Nematode (Caenorhabditis elegans) movement in sand as affected by particle size, moisture and the presence of bacteria (Escherichia coli). Eur. J. Soil Sci. 49:237-241

22. Zhao, X., Schmitt, M., and Hawes, M. C. 2000. Species-dependent effects of border cell and root tip exudates on nematode behavior. Phytopathology 90:1239-1245. 